\title{
Solution to peptide sequencing challenge
}

\section{Juris Meija}

(C) Crown copyright in right of Canada 2012

The winner of the peptide sequencing challenge (published in volume 404, issue 4) is Sami T. Tuomivaara, Complex Carbohydrate Research Center, University of Georgia, Athens, USA

The award entitles the winner to select a Springer book of his choice up to a value of $€ 75$.

Our congratulations!

The cyclic peptide described is kalata B1 [1,2] and its structure is shown in Fig. 1. The partial reduction of the cyclic peptide $[2,3]$ allows one to establish the disulfide connectivity. The first peptide is amino-ethylated at only $\{2\}$ Cys and $\{5\}$ Cys, whereas the second peptide is amino-ethylated at only $\{1\}$ Cys and $\{4\}$ Cys. The original peptide therefore contains disulfide bridges at $\{2\}$ Cys and $\{5\}$ Cys and at $\{1\}$ Cys and $\{4\}$ Cys, and consequently also at $\{3\} \mathrm{Cys}$ and $\{7\} \mathrm{Cys}$.

This article is the solution to the Analytical Challenge to be found at http://dx.doi.org/10.1007/s00216-012-6192-3

J. Meija $(\bowtie)$

National Research Council Canada,

Ottawa, ON K1A 0R6, Canada

e-mail: juris.meija@nrc.ca

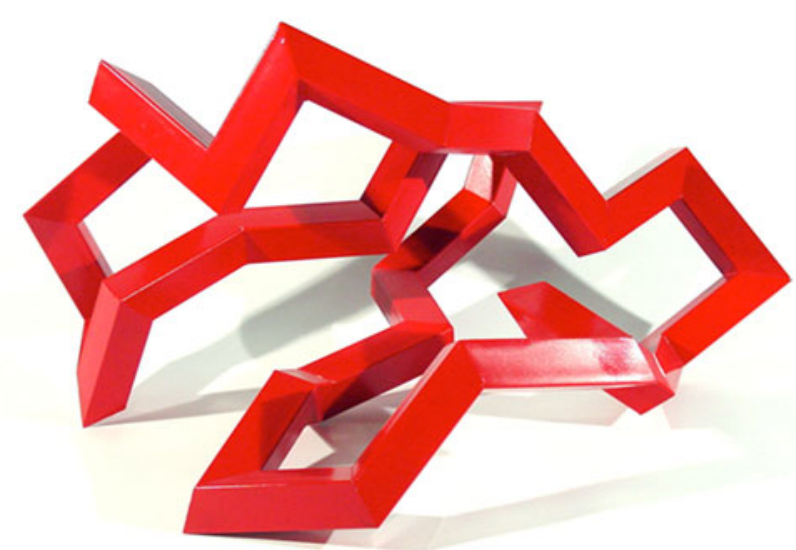

Fig. 1 Kalata, 2002, painted steel, length $3 \mathrm{ft}(90 \mathrm{~cm})$, by Julian Voss-Andreae [4]. The pictured sculpture is based on the structure of the protein kalata $\mathrm{B} 1$

Since this disulfide connectivity cannot be drawn on a plane without any disulfide bonds crossing, kalata B1 forms a nonplanar graph commonly known as the cyclic cystine knot [3].

\section{References}

1. Saether O, Craik DJ, Campbell ID, Sletten K, Juul J, Norman DG (1995) Biochemistry 34:4147-4158

2. Meija J (2012) Anal Bioanal Chem 404:931-932

3. Göransson U, Craik DJ (2003) J Biol Chem 278:48188-48196

4. Voss-Andreae J (2005) Leonardo 38:41-45 